\title{
ACUTE MORPHOLOGICAL AND PHYSIOLOGICAL EFFECTS OF LEAD IN THE NEOTROPICAL FISH Prochilodus lineatus
}

\author{
MARTINEZ, C. B. R., ${ }^{1}$ NAGAE, M. Y., ${ }^{1}$ ZAIA, C. T. B. V. ${ }^{1}$ and ZAIA, D. A. M. ${ }^{2}$ \\ ${ }^{1}$ Departamento de Ciências Fisiológicas \\ ${ }^{2}$ Departamento de Química, Universidade Estadual de Londrina, C.P. 6001, \\ CEP 86051-990, Londrina, Paraná, Brazil \\ Correspondence to: Cláudia B. R. Martinez, Departamento de Ciências Fisiológicas, Universidade Estadual de \\ Londrina, C.P. 6001, CEP 86051-990, Londrina, PR, Brazil, e-mail: cbueno@uel.br \\ Received March 12, 2003 - Aceepted September 26, 2003 - Distributed November 30, 2004
}

(With 5 figures)

\begin{abstract}
The present study investigated lead effects on gill morphology, hematocrit, blood sodium, glucose, lipids, protein, and cholesterol of Prochilodus lineatus exposed to two sublethal lead concentrations for $96 \mathrm{~h}$. Preliminary series of short-term static toxicity tests were run to determine $\mathrm{LC}_{50}(96 \mathrm{~h})$ of lead in P. lineatus, which was $95 \mathrm{mg} \mathrm{Pb} . \mathrm{L}^{-1}$. Therefore, lead concentrations tested in the sublethal experiments were 24 and $71 \mathrm{mg} \mathrm{Pb} . \mathrm{L}^{-1}$, which correspond to $25 \%$ and $75 \%$ of the $\mathrm{LC}_{50}(96 \mathrm{~h})$, respectively. Gills of $P$. lineatus exposed to both lead concentrations during $96 \mathrm{~h}$ presented a higher occurrence of histopathological lesions such as epithelial lifting, hyperplasia, and lamellar aneurism. P. lineatus did not show significant alterations in hematocrit during exposure to both lead concentrations. Fish exposed to the highest lead concentration showed a significant decrease in $\mathrm{Na}^{+}$plasma concentration after $48 \mathrm{~h}$, possibly reflecting a sodium influx rate decrease. P. lineatus exposed to both lead concentrations presented a "classical general adaptation syndrome to stress", as hyperglycemia associated with lowered lipids and proteins was reported. Stressresponse magnitude was dose-dependent. While the response to the lowest lead concentration might represent adaptation, the highest concentration seems to characterize exhaustion.
\end{abstract}

Key words: lead, gill histopathology, Prochilodus lineatus, plasma sodium, stress response.

\section{RESUMO}

\section{Efeitos morfológicos e fisiológicos da exposição aguda ao chumbo na espécie} de peixe neotropical Prochilodus lineatus

O presente estudo investigou os efeitos do chumbo na morfologia branquial, nos hematócritos e nas concentrações plasmáticas de sódio, glicose, lipídeos, proteínas e colesterol de Prochilodus lineatus exposto a duas concentrações subletais de chumbo durante $96 \mathrm{~h}$. Inicialmente, testes agudos (96 h) e estáticos determinaram a $\mathrm{CL}_{50}(96 \mathrm{~h})$ de chumbo para P. lineatus em $95 \mathrm{mg} \mathrm{Pb} \cdot \mathrm{L}^{-1}$. As concentrações de chumbo utilizadas nos testes subletais foram 24 e $71 \mathrm{mg} \mathrm{Pb} . \mathrm{L}^{-1}$, que correspondem a $25 \%$ e $75 \%$, respectivamente, da $\mathrm{CL}_{50}(96 \mathrm{~h})$. As brânquias de $P$. lineatus expostos a ambas as concentrações de chumbo apresentaram maior incidência de lesões histopatológicas, como elevação epitelial, hiperplasia e aneurisma lamelar. P. lineatus não apresentou alterações significativas no hematócrito durante a exposição a ambas as concentrações de chumbo. Peixes expostos a $71 \mathrm{mg} \mathrm{Pb} \cdot \mathrm{L}^{-1}$ apresentaram decréscimo significativo do $\mathrm{Na}^{+}$plasmático após $48 \mathrm{~h}$, o que pode estar se refletindo na redução das taxas de influxo desse íon. $P$. lineatus expostos a ambas as concentrações de chumbo apresentaram resposta clássica ao estresse, como verificado pela hiperglicemia associada ao decréscimo dos lipídeos e proteínas plasmáticas. A magnitude da resposta ao estresse foi dose-dependente. A resposta apresentada na concentração mais baixa representa um processo adaptativo, enquanto na maior concentração caracteriza a exaustão.

Palavras-chave: chumbo, histopatologia branquial, Prochilodus lineatus, sódio plasmático, resposta ao estresse. 


\section{INTRODUCTION}

Lead has a combination of physical and chemical properties that make it extremely useful industrially. Nowadays, the major use of lead is in battery production since a large drop has occurred in the demand for gasoline additives containing lead. In the past, lead use in the chemical industry for preparing paints, pigments, and colored inks was widespread, but many countries, including Brazil, have now restricted this use (WHO, 1995). The natural concentration of lead in surface water has been estimated at $0.02 \mu \mathrm{g} . \mathrm{L}^{-1}$ and it rarely exceeds a few micrograms. $\mathrm{L}^{-1}$. However, high levels of lead are associated with areas in the vicinity of lead mines, smelteries and battery-producing industries. A study conducted by Yabe \& Oliveira (1998) evaluated some metals present in streams in the city of Londrina, Paraná State, in southern Brazil. They reported extremely high lead levels in the water of a stream running nearby a battery industry $\left(4504 \pm 418 \mu \mathrm{g} \mathrm{Pb} \cdot \mathrm{L}^{-1}\right)$.

The impact of metals, as well as other pollutants, on aquatic biota can be evaluated by toxicity tests, which are used to detect and evaluate the potential toxicological effects of chemicals on aquatic organisms. However, little research has been done on the impact of contaminants on tropical ecosystems (Lacher \& Goldstein, 1997). In order to extrapolate meaningful, relevant, and ecologically significant results from aquatic toxicity tests, not only appropriate tests but also appropriate organisms should be used. Whenever possible, species should be studied that are indigenous to, or representative of, the ecosystem that may be impacted (Rand et al., 1995). However, not many native fish species have been employed in toxicity tests in Brazil. Thus almost nothing is known about the sensitivity of Neotropical fish species to chemicals that are potential pollutants in tropical freshwater ecosystems. The same is true for the effects of toxic agents on these fish species. At present, toxicological guidelines for metals in most tropical countries are generally derived from data collected in nontropical ecosystems (Oliveira Ribeiro et al., 1996). A need therefore exists to assess the validity of these guidelines by comparing toxicological effects of various pollutants on fish from tropical, boreal and, eventually, polar regions (Oliveira Ribeiro et al., 2000).

The toxic effects of heavy metals on fish are multidirectional, and manifested by numerous changes in the physiological and chemical processes of their body systems (Dimitrova et al., 1994). Sublethal toxicity of lead to fish produces hematological and neurological effects (Hodson et al., 1984). It is well known that lead causes early mortality of mature red blood cells and inhibition of hemoglobin formation through inhibition of erythrocyte $\boldsymbol{\delta}$-amino levulinic acid dehydratase (ALA-D). The result is anemia at high lead exposures or compensating erythropoiesis at lower exposures (Hodson, 1976; Hodson et al., 1977; Hodson et al., 1978a, b). Neurological effects include impaired learning behaviour, darkening of the caudal region (black tails), and eventual spinal curvatures (Hodson et al., 1978a, 1979, 1980). Lead can also affect glucose metabolism as showed by Salmerón-Flores et al. (1990), who reported increased glucose blood concentration in Sarotherodum aureus in response to lead exposure. A strong hyperglycemic response was also observed in fish exposed to other metals, such as cadmium and copper (Donaldson, 1981).

Exposure of fish to heavy metals may also result in variable degrees of ion regulatory disruption, and plasma ion levels may be employed for quantifying toxic effects of metals during acute exposure (Mayer et al., 1992). In freshwater fish, osmotic water influx and diffusive losses of ions such as $\mathrm{Na}^{+}$and $\mathrm{Cl}^{-}$are compensated for by the excretion of large volumes of dilute urine and active uptake to replace ions lost by the gills (Evans et al., 1999). In constant contact with the water, the gill is a sensitive primary target for a variety of insults including heavy metals (Hinton et al., 1992). Given that the gills are the major sites of osmotic and ionic regulation in fish, any changes in gill morphology may result in perturbed osmotic and ionic status.

The present study investigated lead effects on some morphological and physiological parameters of the neotropical freshwater fish Prochilodus lineatus (Valenciennes, 1847) (= Prochilodus scrofa Steindachner, 1881). A very common fish species of the Paraná basin (southern Brazil) and an important food source, $P$. lineatus is a neotropical fish suitable for pollutant effect assessment. Besides, according to Mazon \& Fernandes (1999), juvenile specimens of $P$. scrofa are potential vertebrate bioindicator organisms for environmental monitoring. In order to evaluate lead effects, we examined gill morphology, hematocrit, blood sodium, glucose, lipids, protein, and cholesterol of $P$. lineatus exposed to two sublethal lead concentrations. 


\section{MATERIAL AND METHODS}

\section{Experimental animals}

Juveniles of Prochilodus lineatus (mean mass: $11.88 \mathrm{~g}$; range: $7.90-15.25$ ) were obtained from the Universidade Estadual de Londrina hatchery station. They were held in a $600 \mathrm{~L}$ tank, with continuously aerated well water $\left(\mathrm{T}=21^{\circ} \mathrm{C}, \mathrm{pH}=7.4\right.$, hardness $=$ $80 \mathrm{mg} . \mathrm{L}^{-1} \mathrm{CaCO}_{3}$ ), with a $14 \mathrm{~h} / 10 \mathrm{~h}$ light/dark cycle, for at least 7 days prior to experiments. Fish were fed ad libitum with pellet food each 48 h, except during and on the day preceding the experiments.

\section{$L C_{50}$ determination}

Preliminary series of short-term (96 h) static toxicity tests were run to determine the median lethal concentration $\left(\mathrm{LC}_{50}\right)$ of lead for $P$. lineatus according to SEMA (1988). Experiments were performed in $100 \mathrm{~L}$ glass aquaria containing 6 fish each. Water was continuously aerated, light/dark regime was 14/10 h, water temperature was kept at $21 \pm 1^{\circ} \mathrm{C}, \mathrm{pH} 7.5$, and water hardness was $82 \mathrm{mg} . \mathrm{L}^{-1} \mathrm{CaCO}_{3}$. The test consisted of six groups of six animals each exposed to one of the following nominal lead concentrations: 0 (control), 98, 146, 219, 328, and $493 \mathrm{mg} . \mathrm{L}^{-1}$ total lead. Mortality and abnormal behavioural responses were recorded every $12 \mathrm{~h}$, during 96 hours. Lead was added to the water as $\mathrm{Pb}\left(\mathrm{NO}_{3}\right)_{2}$ (reagent grade) (Vetec, Brazil). The $\mathrm{LC}_{50}$ values for 24 and $96 \mathrm{~h}$ were estimated by the trimmed Spearman-Karber method (Hamilton et al., 1977).

\section{Sublethal toxicity tests}

In order to evaluate lead effects, fish were exposed to two sublethal lead nitrate concentrations corresponding to $25 \%$ and $75 \%$ of the $\mathrm{LC}_{50}(96 \mathrm{~h}$ ). For each lead concentration seven groups, of six fish each, were held in $100 \mathrm{~L}$ glass aquaria and one experimental group was terminally sampled at one of the following intervals: $6,12,24,48,72$, and $96 \mathrm{~h}$. Control group consisted of 6 animals exposed only to water, without lead, sampled after $96 \mathrm{~h}$. Water temperature, $\mathrm{pH}$, hardness, as well as day/light regime were the same as reported above.

Immediately after removal of the fish from the water, blood samples were taken from the caudal vein by heparinized plastic syringes. After blood sampling, fish were killed by cervical section, and the second and third gill arches from the right side were immediately removed.

\section{Gill histopathology}

Gills samples were placed in Bouin's fixative for 8 hours, then transferred to ethanol $70 \%$, and finally dehydrated in an increasing ethanol series and embedded in Paraplast (Oxford Plus). The tissue was sectioned at $7 \mu \mathrm{m}$ and stained with hematoxylin-eosin. At least two slides with 4 to 5 sections of each gill were examined under an Olympus microscope (Model CH30LF100) and documented using a Zeiss photomicroscope (Axiophot).

Histopathological alterations were evaluated semiquantitatively by ranking tissue lesion severity. Ranking was as follows: grade $1=$ no pathological alterations; grade 2 = mild to moderate focal changes; and grade 3 = extended severe pathological alterations. This ranking was used by Schwaiger et al. (1997) to establish at an overall assessment value of the histopathological lesion for each individual fish gill. Based on the value attributed to each animal, a Mean Assessment Value (MAV) of gill lesions was calculated for each treatment group.

\section{Blood analysis}

Hematocrit (Hct) values were determined by blood centrifugation ( $5 \mathrm{~min}, 5,000 \mathrm{~g}$ ) in glass capillaries, using a microhematocrit centrifuge (Luguimac S.R.L., Model LC 5, Argentina). Blood samples were then centrifuged ( $5 \mathrm{~min}, 12,000 \mathrm{~g}$ ) using a Centrimicro (Fanem, Model 243, Brazil) and plasma samples were stored frozen $\left(-20^{\circ} \mathrm{C}\right)$ until chemical analyses. Plasma sodium concentrations were measured by flame photometry (Analyser, Model 900, Brazil). Plasma glucose concentrations were measured by spectrophotometry using a glucose/peroxidase enzymatic assay (KIT GLUCOX 500 - Doles Reagentes, Brazil). Total lipid and cholesterol concentrations in blood plasma were determined by a spectrophotometric enzymatic methods using a commercial kit (Analisa, Brazil). Total proteins in blood plasma were measured using spectrophotometric determination with $\boldsymbol{\rho}-$ benzoquinone following Zaia et al. (1992). All samples were analyzed in triplicate in a spectrophotometer (Shimadzu, Model 1203 UV, Japan).

\section{Statistical analyses}

For each parameter analyzed, differences among groups exposed to the same lead concentration for different time periods, including the control group, were tested for significance by oneway parametric ANOVA and multiple range tests 
(Student-Newman-Keuls procedure) where appropriate. Means were considered significantly different where $\mathrm{p}<0.05$. All tests were done using Primer of Biostatistics Software (Ver. 1.0, McGraw-Hill, Inc., USA) according to Zar (1996).

\section{RESULTS}

$L C_{50}$

The short-term lethality test gave $24 \mathrm{~h} \mathrm{LC}_{50}$ of $126 \mathrm{mg} \mathrm{Pb} . \mathrm{L}^{-1}$ and $96 \mathrm{~h} \mathrm{LC}_{50}$ of $95 \mathrm{mg} \mathrm{Pb} . \mathrm{L}^{-1}$. Therefore, lead concentrations tested on the sublethal experiments were 24 and $71 \mathrm{mg} \mathrm{Pb} . \mathrm{L}^{-1}$ corresponding to $25 \%$ and $75 \%$ of the $96 \mathrm{~h} \mathrm{LC}_{50}$, respectively. These values are related to total metal concentrations added to the test media.

\section{Gill histopathology}

Histopathological changes in both epithelia and blood vessels were observed in gills of $P$. lineatus exposed to lead. The lesions observed in the gills of animals exposed to the lowest lead concentration consisted primarily of epithelial lifting, which is characterized by a lifting of the outer layer of the lemellar epithelium (Fig. 1a). Hyperplasia, an increased proliferation of cells, could be observed only in animals exposed to $71 \mathrm{mg} \mathrm{Pb} . \mathrm{L}^{-1}$ of the pollutant, and occasionally resulted in fusion of adjacent lamellae and even of adjacent filaments. Erythrocyte congestion throughout the entire lamella (aneurism) could be observed in almost all experimental intervals in gills of animals exposed to both lead concentrations (Fig. 1b).

As indicated by the mean assessment value for gill lesions (Table 1), based on semi-quantitative evaluation of findings histopathological alterations showed a trend to increase with time of exposure to lead, and $P$. lineatus exposed to both lead concentrations during $96 \mathrm{~h}$ presented a MAV significantly higher than control animals $(\mathrm{p}<0.05)$.

\section{Blood parameters}

$P$. lineatus did not show significant hematocrit alterations during exposure to either lead concentration (Fig. 2).

In animals exposed to $24 \mathrm{mg} \mathrm{Pb} . \mathrm{L}^{-1}$, plasma $\mathrm{Na}^{+}$concentrations tended to decrease after $12 \mathrm{~h}$ and recovery to control values was observed after
$96 \mathrm{~h}$, but the differences were not statistically significant in relation to control. In fish exposed to $71 \mathrm{mg} \mathrm{Pb} . \mathrm{L}^{-1}$ during $48 \mathrm{~h}$, plasma $\mathrm{Na}^{+}$concentration was significantly lower than in the control group (Fig. 3).

Blood glucose concentrations increased significantly in animals exposed to $24 \mathrm{mg} \mathrm{Pb} . \mathrm{L}^{-1}$ during 6 and $12 \mathrm{~h}$; lipid concentrations decreased significantly after $6 \mathrm{~h}$ of exposure to the same lead concentration (Fig. 4). In fish exposed to $71 \mathrm{mg} \mathrm{Pb.L^{-1 }}$ during 6 and $24 \mathrm{~h}$, blood glucose increased significantly whereas lipid concentrations decreased significantly in relation to control values. These animals also presented a significant reduction in blood proteins in all experimental periods after $24 \mathrm{~h}$. Cholesterol concentrations decreased steadily at all exposure times (Fig. 5).

\section{DISCUSSION}

The values obtained by toxicity testing (e.g., $\mathrm{LC}_{50}$ ) are very dependent on the conditions under which tests were performed, so that interpretation of $\mathrm{LC}_{50}$ values needs to be done with caution (Walker et al., 1996). Amongst fish species, considerable differences in sensitivity to lead have been reported (Salmerón-Flores et al., 1990). According to Demayo et al. (1981), lead toxicity is a function of water hardness, species tested, and fish age. Increased water hardness reduces lead toxicity to fish due to a significant inorganic complexation process that controls lead availability to fish (Hodson et al., 1984). Pickering and Henderson (1966) showed that in soft water $\left(20 \mathrm{mg} \mathrm{CaCO} \mathrm{CL}^{-1}\right)$ the $96 \mathrm{~h}-\mathrm{LC}_{50}$ for Pimephales promelas and Lepomis macrochirus was 5.6 and $23.8 \mathrm{mg} \mathrm{Pb} . \mathrm{L}^{-1}$, whereas in hard water $(360$ $\left.\mathrm{mg} \mathrm{CaCO} \cdot \mathrm{L}^{-1}\right) 96 \mathrm{~h}-\mathrm{LC}_{50}$ was 482 and $442 \mathrm{mg} \mathrm{Pb} . \mathrm{L}^{-1}$, respectively. The short-term lethality test conducted in this study yielded $96 \mathrm{~h}-\mathrm{LC}_{50}$ of $95 \mathrm{mg} \mathrm{Pb} . \mathrm{L}^{-1}$ for juveniles of $P$. lineatus in water of $82 \mathrm{mg} . \mathrm{L}^{-1}$ hardness $\left(\mathrm{CaCO}_{3}\right)$. Besides differences related to water hardness and fish age, all the results reported above were derived from static bioassays in which lead content could vary due to absorption, adsorption, and precipitation, which makes comparisons between $P$. lineatus lead sensitivity with that of other fish species far more complex. 
TABLE 1

Mean assessment values (MAV) of gill alterations in P. lineatus after 6, 12, 24, 48, 72, and $96 \mathrm{~h}$ exposure to different lead concentrations, 24 or $71 \mathrm{mg} \mathrm{Pb} . \mathrm{L}^{-1}$. Control animals were exposed only to water without lead during $96 \mathrm{~h}$.

\begin{tabular}{|c|c|c|}
\hline Time & 24 mg.. & 71 $\mathbf{~ m g . \mathbf { L } ^ { - 1 }}$ \\
\hline Control & $1.20 \pm 0.45(5)$ & $1.33 \pm 0.52(6)$ \\
\hline $6 \mathrm{~h}$ & $1.67 \pm 0.52(6)$ & $2.00 \pm 0.00(5)$ \\
\hline $12 \mathrm{~h}$ & $1.75 \pm 0.50(4)$ & $2.00 \pm 0.00(5)$ \\
\hline $24 \mathrm{~h}$ & $1.60 \pm 0.55(5)$ & $2.50 \pm 0.58(4)$ \\
\hline $48 \mathrm{~h}$ & $2.00 \pm 0.00(5)$ & $2.40 \pm 0.55(5)$ \\
\hline $72 \mathrm{~h}$ & $2.20 \pm 0.45(5)$ & $2.33 \pm 0.58(5)$ \\
\hline $96 \mathrm{~h}$ & $2.40 \pm 0.55(5)^{*}$ & $2.67 \pm 0.58(5)^{*}$ \\
\hline
\end{tabular}

Values are reported as means \pm S.D. (number of animals).

* Indicates significant difference from control $(\mathrm{p}<0.05)$.
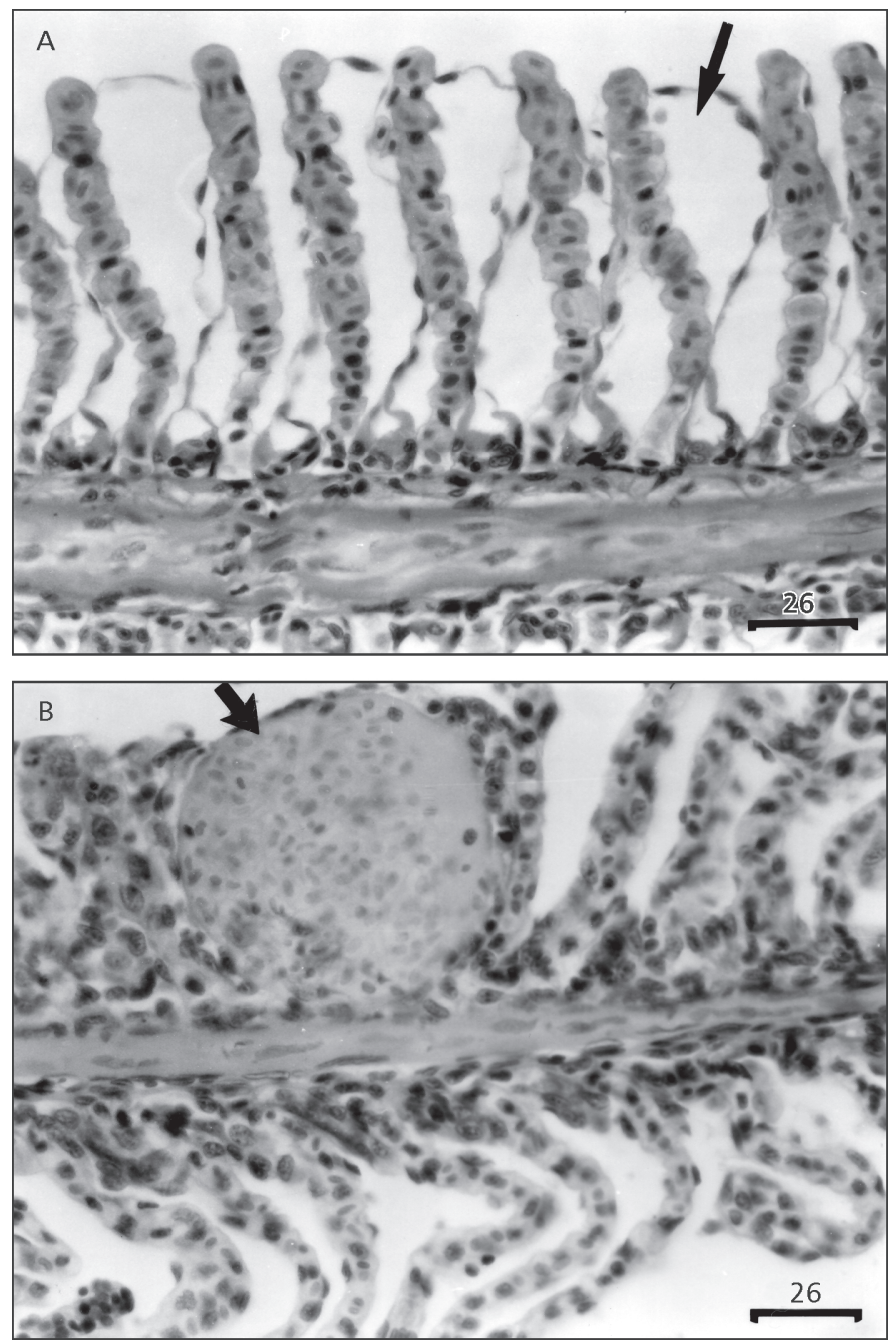

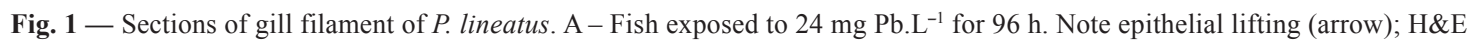
stain, scale bar in $\mu \mathrm{m}$. B - Fish exposed to $71 \mathrm{mg} \mathrm{Pb.L^{-1 }}$ for $96 \mathrm{~h}$. Note lamellar aneurism (arrow); H\&E stain, scale bar in $\mu \mathrm{m}$. 

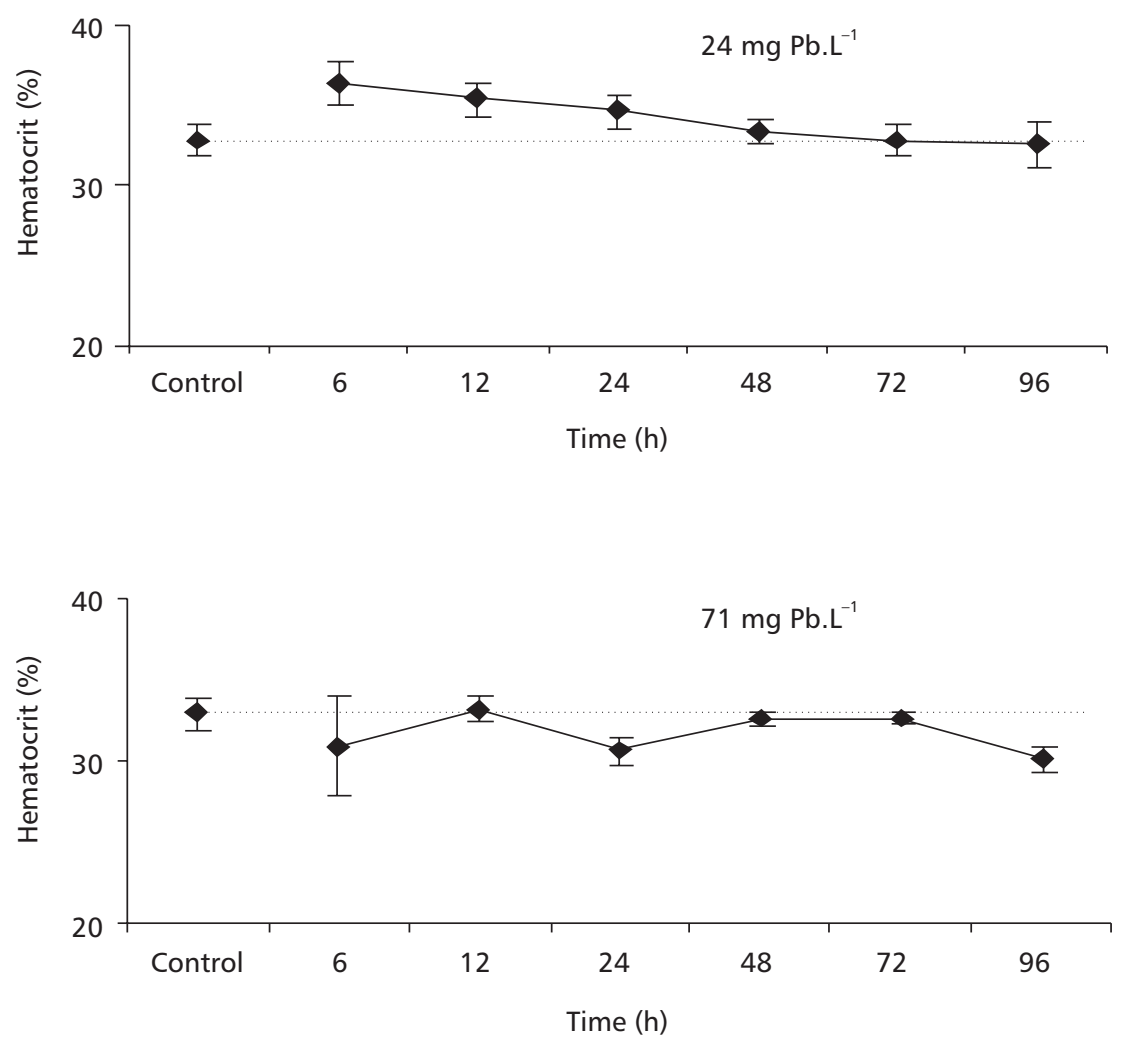

Fig. 2 - Haematocrit of $P$. lineatus after $6,12,24,48,72$, and $96 \mathrm{~h}$ exposure to different lead concentrations, $24 \mathrm{or} 71 \mathrm{mg} \mathrm{Pb} . \mathrm{L}^{-1}$. Control animals were exposed only to water, without lead, during $96 \mathrm{~h}$. The values are mean \pm S.E.

Acute exposure to some chemicals can cause rapid destruction of gill lamellae within a few hours (Heath, 1987). In fact, gills of P.lineatus exposed to lead nitrate during 96 hours presented a higher occurrence of histopathological lesions such as epithelial lifting, hyperplasia, and lamellar aneurism. Rather than reflecting direct toxic action, lifting and hyperplasia of the lamellar epithelium could be interpreted as defense responses of the fish, as these alterations increase the distance across which waterborne irritants must diffuse to reach the bloodstream (Mallat, 1985). These changes in gill epithelia were also observed in P. scrofa acutely exposed to copper (Mazon et al., 2002). Epithelial lifting and hyperplasia of undifferentiated epithelial cells are known to be nonspecific alterations, which can be caused by a variety of unrelated insults such as those caused by heavy metals (Heath, 1987; Hinton et al., 1992; Randy et al., 1996). On the other hand, heavy metals were least often associated with lamellar aneurism, a lesion that seems to involve pillar cell disruption. Mallat (1985) suggested that pillar cells may be more resistant to metals than to most other kinds of irritants. However, the present study and the one by Mazon et al. (2002) showed that lead and copper, respectively, can cause lamellar aneurism in Prochilodus gills.

These branchial responses that would serve to slow entry of lead have the undesirable side effect of reducing oxygen diffusion, since they increase the water-blood distance for gas diffusion (Mallat, 1985). A pollutant that results in gill damage and subsequent internal hypoxia can be expected to cause a hematocrit increase, which might be due to swelling of the erythrocytes. This occurs whenever fish blood cells are exposed to hypoxia. However, no significant change was observed in hematocrit of $P$. lineatus exposed to both lead concentrations, indicating that despite gill lesions, the animals were not exposed 
to an internal hypoxia. When Hodson et al. (1978a) chronically exposed rainbow trout to waterborne lead, they also observed that hematocrit was unaffected by metal exposure.

During exposure to waterborne heavy metals, the active uptake of ions from the water may be initially impaired, leading to ionic homeostasis disturbances (McDonald \& Wood, 1993). Mazon et al. (2002) reported that in P. scrofa exposed to lethal and sublethal copper concentrations, plasma $\mathrm{Na}^{+}$ decreased significantly. In addition, Pelgrom et al. (1995) showed that in Oreochromis mossambicus exposed to cadmium and copper for 6 days, plasma $\mathrm{Na}^{+}$concentrations decreased markedly in $\mathrm{Cu}$-exposed fish, while producing less pronounced effects in $\mathrm{Cd}$ exposed fish. In this study a significant decrease was observed in $\mathrm{Na}^{+}$plasma concentration in animals exposed to the highest lead concentration for 48 hours, recovery of this parameter to control values occurring after 72 hours. This sodium decrease might reflect a decrease in the sodium influx rate. The mechanism of osmoregulatory disruption by metals normally involves inhibition of $\mathrm{Na}^{+} / \mathrm{K}^{+}$-ATPase enzymes in gills and perhaps in the gut as well. Therefore, lead might be inhibiting gill $\mathrm{Na}^{+} / \mathrm{K}^{+}$-ATPase on $P$. lineatus, what may cause a disruption on sodium hyperregulation. Some authors suggest that if the extent of ion alteration is not too great, recovery of osmoionic homeostasis may occur, even with continued pollutant exposure, and cortisol is probably key in this process (Jobling, 1994; Wendelaar Bonga, 1997). Lead is a potent inhibitor of $\mathrm{Na}^{+} / \mathrm{K}^{+}$-ATPase activity, which was clearly demonstrated by a $50 \%$ reduction of $\mathrm{Na}^{+} / \mathrm{K}^{+}$-ATPase activity of the freshwater crayfish Cherax destructor incubated in vitro with $120 \mathrm{mg} \mathrm{Pb} . \mathrm{L}^{-1}$ (Ahern \& Morris, 1998).
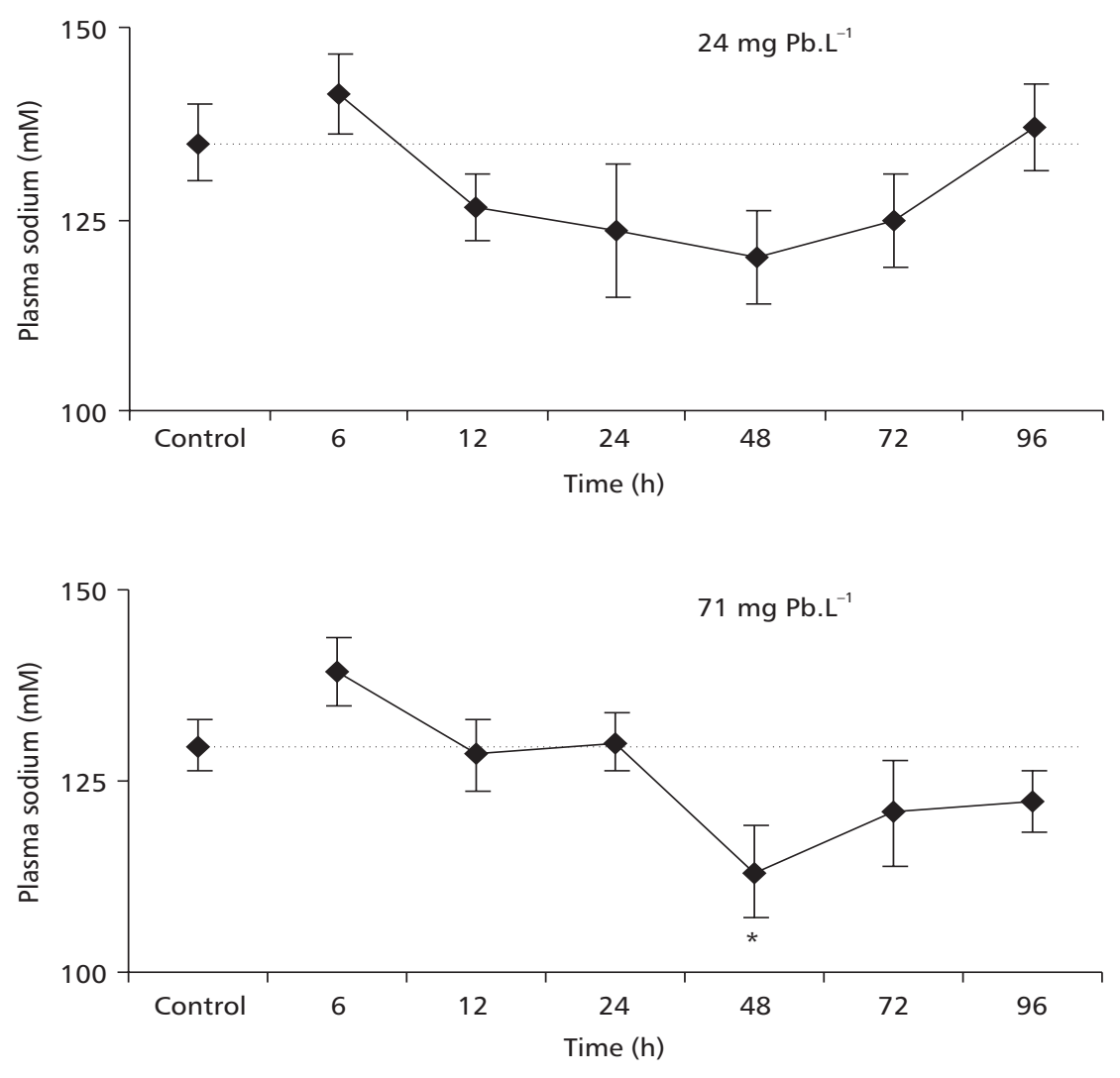

Fig. 3 - Plasma sodium concentrations of $P$. lineatus after 6, 12, 24, 48, 72, and 96 h exposure to different lead concentrations,

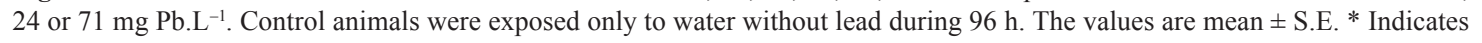
significance difference from the control $(\mathrm{p}<0.05)$. 

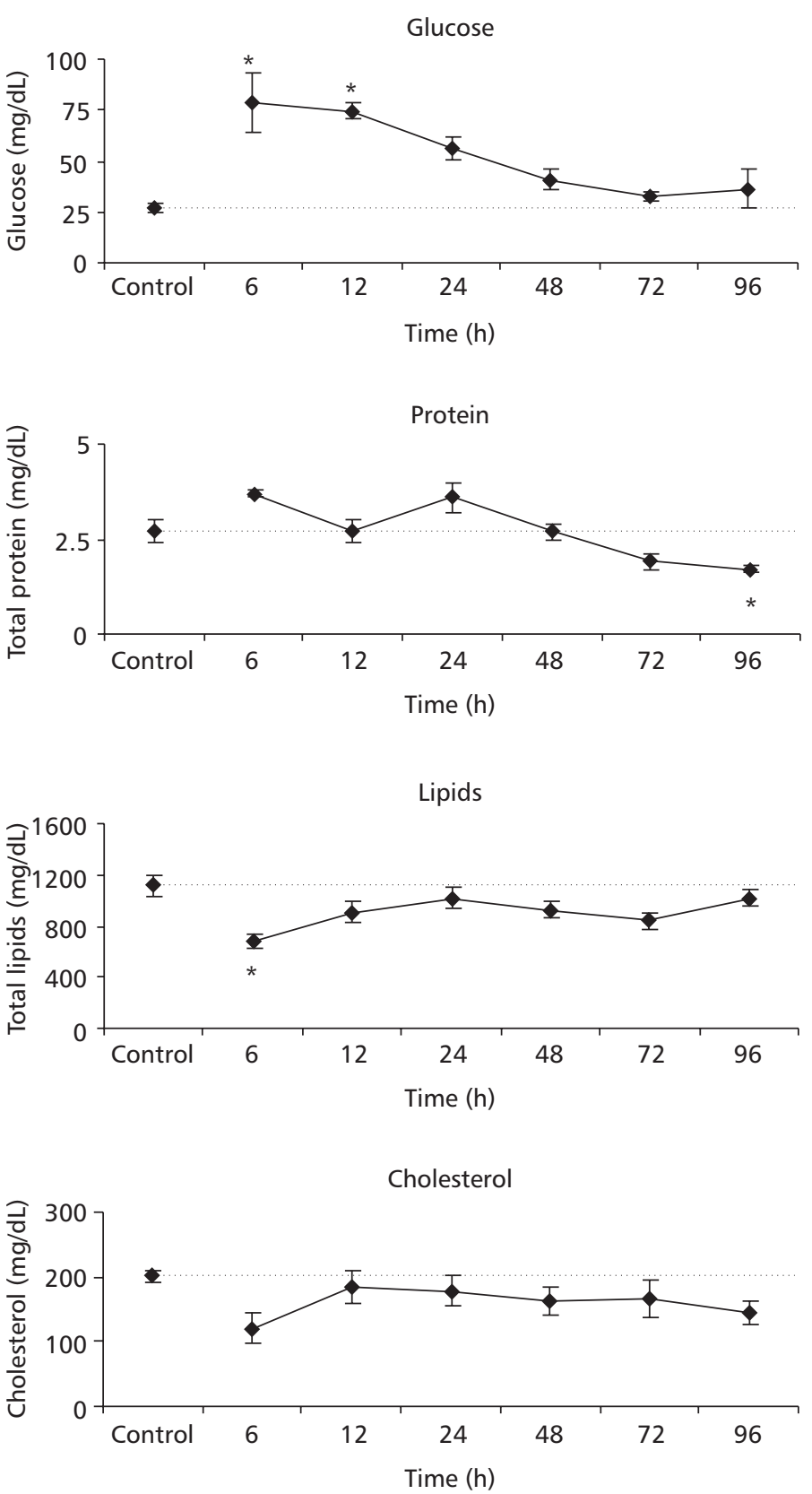

Fig. 4 - Plasma glucose, total proteins, total lipid and cholesterol concentrations of $P$. lineatus after 6, 12, 24, 48, 72, and $96 \mathrm{~h}$ exposure to $24 \mathrm{mg} \mathrm{Pb} . \mathrm{L}^{-1}$. Control animals were exposed only to water without lead during $96 \mathrm{~h}$. The values are mean \pm S.E. *Indicates significance difference from the control $(\mathrm{p}<0.05)$. 

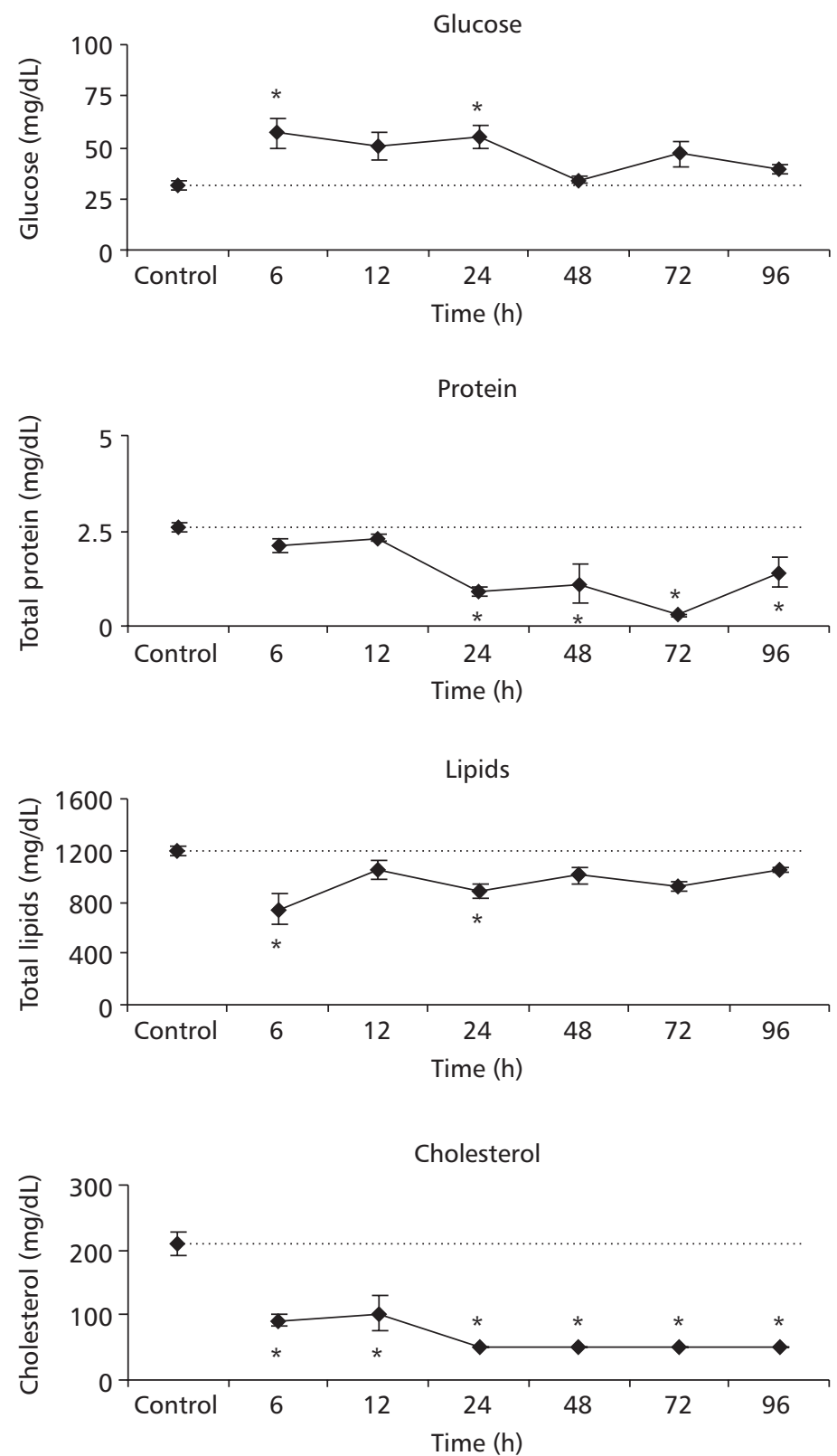

Fig. 5 - Plasma glucose; total protein, total lipid, and cholesterol concentrations of P. lineatus after 6, 12, 24, 48, 72, and $96 \mathrm{~h}$ exposure to $71 \mathrm{mg} \mathrm{Pb} . \mathrm{L}^{-1}$. Control animals were exposed only to water without lead during $96 \mathrm{~h}$. The values are mean \pm S.E. *Indicates significance difference from the control $(\mathrm{p}<0.05)$. 
Several heavy metals have been reported to stimulate interrenal activity and plasma corticosteroid and glucose levels in fish (Pratap \& Wendelaar Bonga, 1990). Hypersecretion of adrenalin and cortisol are considered primary stress responses. These effects trigger a broad suite of biochemical and physiological alterations called secondary stress responses. Metabolic effects include hyperglycemia, depletion of tissue glycogen reserves, catabolism of muscle protein, and altered blood levels of protein, cholesterol, and free fatty acids (Thomas, 1990; Jobling, 1994; Wendelaar Bonga, 1997). P. lineatus exposed to both lead concentrations presented a "classical general adaptation syndrome to stress", since hyperglycemia associated with decreased lipids and proteins was reported. The stress-response magnitude was dosedependent: animals exposed to $24 \mathrm{mg} \mathrm{Pb} . \mathrm{L}^{-1}$ showed a larger glucose increase followed by a lesser protein and lipids decrease, with no change in cholesterol

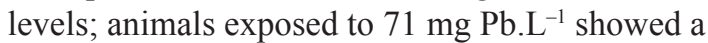
slight glucose increase, followed by a larger protein and lipid decrease, and also a cholesterol decrease. The response to the lowest lead concentration might represent adaptation, while that for the highest concentration seems to characterize exhaustion. Adaptation, implying changes in several related physiological processes, permits homeostasis return. Exhaustion, however, may occur if the extent of stress is sufficient and characterized by a depletion of liver glycogen, decreasing cortisol levels, and a host of other changes making the organism less able to survive.

In conclusion, $P$. lineatus acutely exposed to lead presented histopathological gill lesions, temporary disturbances in sodium regulation, and showed a classical response to stress, since hyperglycemia associated to lowered lipids and proteins was reported. The stress-response magnitude was dose-dependent. Response at the highest concentration seems to characterize exhaustion, which makes the organism less able to survive especially if other types of stressors are present.

Acknowledgements - The authors thank the Universidade Estadual de Londrina hatchery station (EPUEL) for supplying the fish used. This study was supported by UEL/COPATI/KLABIN and CNPq (grant to C.T.B.V.Z.).

\section{REFERENCES}

AHERN, M. D. \& MORRIS, S., 1998, Accumulation of lead and its effects on $\mathrm{Na}$ balance in the freshwater crayfish Cherax destructor. J. Exp. Zool., 281: 270-279.
DEMAYO, A., TAYLOR, M. C., TAYLOR, K. W. \& HODSON, P. V., 1981, Toxic effects of lead and lead compounds on human health, aquatic life, wildlife plants, and livestock. Critical Reviews in Environmental Control, 12(4): 257-305.

DIMITROVA, M. S., TISHINOVA, T. \& VELCHEVA, V., 1994, Combined effects of zinc and lead on the hepatic superoxide dismutase-catalase system in carp. Comp. Biochem. Physiol., 108C: 43-46.

DONALDSON, E. M., 1981, The pituitary-interrenal axis as indicator of stress in fish. In: A. D. Pickering (ed.), Stress and fish. Academic Press, London.

EVANS, D. H., PIERMARINI, P. M. \& POTTS, W. T. W., 1999, Ionic transport in the fish gill epithelium. J. Exp. Zool., 283: 641-652.

HAMILTON, M. A., RUSSO, R. C. \& THURSTON, R. V., 1977, Trimmed Spearman-Karber method, for estimating median lethal concentrations in toxicity bioassays. Environ. Sci. Technol., 11(7): 714-719. Correction, 12(4): 417, 1978.

HEATH, A. G., 1987, Water pollution and fish physiology. CRC Press, Boca Raton, Fl.

HINTON, D. E., BAUMANN, P. C., GARDNER, G. R., HAWKINS, W. E., HENDRICKS, J. D., MURCHELANO, R. A. \& OKIHIRO, M. S., 1992, Histopathological biomarkers. In: R. J. Huggett, R. A. Kimerle, P. M. Mehrle-Jr. \& H. L. Bergman (eds.), Biomarkers: biochemical, physiological, and histological markers of anthropogenic stress. Lewis Publishers, Boca Raton, Fl.

HODSON, P. V., 1976, $\boldsymbol{\delta}$-amino levulinic acid dehydratase activity of fish blood as an indicator of a harmful exposure to lead. J. Fish. Res. Board Can., 33: 268-271.

HODSON, P. V., BLUNT, B. R., SPRY, D. J. \& AUSTEN, K., 1977, Evaluation of erythrocyte $\boldsymbol{\delta}$-amino levulinic acid dehydratase activity as a short-term indicator in fish of a harmful exposure to lead. J. Fish. Res. Board Can., 34: 501-508.

HODSON, P. V., BLUNT, B. R. \& SPRY, D. J., 1978a, Chronic toxicity of waterborne and dietary lead to rainbow trout (Salmo gairdneri) in lake Ontario water. Water Res., 12: 869-878.

HODSON, P. V., BLUNT, B. R. \& SPRY, D. J., 1978b, pHinduced changes in blood lead of lead-exposed rainbow trout (Salmo gairdneri). J. Fish. Res. Board Can., 35: 437-445.

HODSON, P. V., BLUNT, B. R., JENSEN, D. \& MORGAN, S., 1979, Effect of fish age on predicted and observed chronic toxicity of lead to rainbow trout in lake Ontario water. $J$. Great Lakes Res., 5: 84-89.

HODSON, P. V., HILTON, J. W., BLUNT, B. R. \& SLINGER, S. J., 1980, Effect of dietary ascorbic acid on chronic lead toxicity to young rainbow trout (Salmo gairdneri). Can. J. Fish. Aquat. Sci., 37: 170-176.

HODSON, P. V., WhitTle, D. M., WONG, P. T. S., BORGMANN, U., THOMAS, R. L., CHAU, Y. K., NRIAGU, J. O. \& HALLET, D. J., 1984, Lead contamination of the Great Lakes and its potential effects on aquatic biota. In: J. O. Nriagu \& M. S. Simmons (eds.), Toxic contaminants in the Great Lakes. John Wiley and Sons, Indianapolis, In. 
JOBLING, M., 1994, Fish bioenergetics. Chapman \& Hall, London.

LACHER, T. E. \& GOLDSTEIN, M. I., 1997, Tropical ecotoxicology: status and needs. Environ. Toxicol. Chem. 16(1): 100-11.

MALLAT, J., 1985, Fish gill structural changes induced by toxicants and other irritants: a statistical review. Can. J. Fish. Aquat. Sci., 42: 630-648.

MAYER, F. L., VERSTEEG, D. J., MCKEE, M. J., FOLMAR, L. C., GRANEY, R. L., MCCUME, D. C. \& RATTNER, B. A., 1992, Physiological and non-specific biomarkers. In: R. J. Huggett, R. A. Kimerle, P. M. Mehrle-Jr. \& H. L. Bergman (eds.), Biomarkers: biochemical, physiological, and histological markers of anthropogenic stress. Lewis Publishers, Boca Raton, Fl.

MAZON, A. F. \& FERNANDES, M. N., 1999, Toxicity and differential tissue accumulation of copper in the tropical freshwater fish, Prochilodus scrofa (Prochilodontidae). Bull. Environ. Contam. Toxicol., 63: 797-804.

MAZON, A. F., MONTEIRO, E. A. S., PINHEIRO, G. H. D. \& FERNANDES, M. N., 2002, Hematological and physiological changes induced by short-term exposure to copper in the freshwater fish, Prochilodus scrofa. Braz. J. Biol., 62(4A): 621-631.

MCDONALD, D. G. \& WOOD, C. M., 1993, Branchial mechanisms of acclimation to metals in freshwater fish. In: J. C. Rankin \& F. B. Jensen (eds.), Fish ecophysiology - fish and fisheries series 9. Chapman and Hall, London.

OLIVEIRA RIBEIRO, C. A., FANTA, E., TURCARATTI, N. M., CARDOSO, R. J. \& CARVALHO, C. S., 1996, Lethal effects of inorganic mercury on cells and tissues of Trichomycterus brasiliensis (Pisces, Siluroidei). Biocell, 20: 171-178.

OLIVEIRA RIBEIRO, C. A., PELLETIER, E., PFEIFFER, W C. \& ROULEAU, C., 2000, Comparative uptake, bioaccumulation, and gill damages of inorganic mercury in tropical and Nordic freshwater fish. Environ. Research, 83(A): 286-292.

PELGROM, S. M. G. J., LOCK, R. A. C., BALM, P. H. M. \& WENDELAAR BONGA, S. E., 1995, Effects of combined waterborne $\mathrm{Cd}$ and $\mathrm{Cu}$ exposures on ionic composition and plasma cortisol in tilapia, Oreochromis mossambicus. Comp. Biochem. Physiol., 111(c): 227-235.

PICKERING, Q. H. \& HENDERSON, P., 1966, The acute toxicity of some heavy metals to different species of warmwater fishes. Int. J. Air Water Pollut., 10: 453-463.

PRATAP, H. B. \& WENDELAAR BONGA, S. E., 1990 Effects of water-borne cadmium on plasma cortisol and glucose in the cichlid fish Oreochromis mossambicus. Comp. Biochem. Physiol., 95(C): 313-317.
RAND, G. M., WELLS, P. G. \& MCCARTHY, L. S., 1995, Introduction to aquatic toxicology. In: G. M. Rand (ed.), Fundamentals of aquatic toxicology: effects, environmental fate and risk assessment. $2^{\text {nd }}$ ed. Taylor \& Francis, Washington, DC.

RANDY, A. S., MONSERRAT, J. M., RODRIGUEZ, E. M. \& ROMANO, L. A., 1996, Histpathological effects of cadmium on the gills of the freshwater fish Macropsobrycon uruguayanae Eigenmann (Pisces, Atherinidae). J. Fish Dis., 19: 311-322.

SALMERÓN-FLORES, P., MELENDEZ-CAMARGO, M. E. \& MARTINEZ-TABCHE, L., 1990, Efecto hepatotóxico y nefrotóxico del plomo sobre la tilapia (Sarotherodon aureus). An. Esc. Nac. Cienc. Biol. Mex., 33: 147-156.

SCHWAIGER, J., WANKE, R., ADAM, S., PAWERT, M., HONNEN, W. \& TRIEBSKORN, R., 1997, The use of histopathological indicators to evaluate contaminant-related stress in fish. J. Aquat. Ecosyst. Stress and Recov., 6(1): 75-86.

SEMA, 1988, Manual de testes para avaliação da ecotoxicidade de agentes químicos. Secretaria Especial do Meio Ambiente, Brasília.

THOMAS, P., 1990, Molecular and biochemical responses of fish to stressors and their potential use in environmental monitoring. In: S. M. Adams (ed.), Biological indicators of stress in fish. American Fisheries Society, Bethesda, Maryland.

WALKER, C. H., HOPKIN, S. P., SIBLY, R. M. \& PEAKALL, D. B., 1996, Principles of ecotoxicology. Taylor \& Francis, London.

WENDELAAR BONGA, S. E., 1997, The stress response in fish. Physiol. Rev., 77: 591-625.

WHO, 1995, Environmental health criteria 85: Lead environmental aspects. World Health Organization, Geneva.

YABE, M. J. S. \& OLIVEIRA, E. O., 1998, Metais pesados em águas superficiais como estratégia de caracterização de bacias hidrográficas. Química Nova, 21: 551-556.

ZAIA, D. A. M., OBARA, M. M., ROCKENBACH, S. R., BARRETO, W. J., GAZIRI, L. C. J., ZAIA, C. T. B. V. \& LICHTIG, J., 1992, Spectrophotometric determination of total proteins in blood plasma with $\rho$-benzoquinone. Braz. J. Med. Biol. Res., 25: 549-555.

ZAR, J. H., 1996, Biostatistical analysis. $3^{\text {rd }}$. ed. Prentice Hall, New Jersey. 
O arquivo disponível sofreu correções conforme ERRATA publicada no Volume 65 Número 2 da revista. 